\title{
Viena - logo ali e tão distante
}

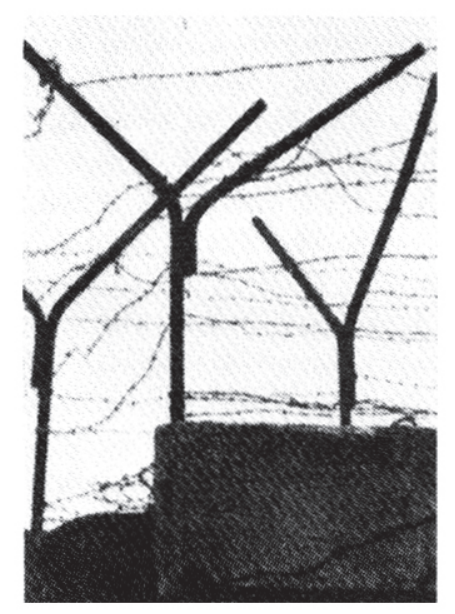

\section{Anna Veronica Mautner}

\section{INTRODUÇÃO}

- Mas, tio, por que em outros parses do Leste a psicanálise morreu (ou quase) e aqui manteve-se e logo que pôde se expandiu? O que faz aqui ser diferente dali?

- Acho que foi porque o atendimento particular nunca foi completamente proibido(1), diz dr. Paulo Braun, médico clínico, ex-diretor de um hospital geral de Budapeste (Robert Szanatorinm), por mais de $\mathbf{4 0}$ anos.

- Mas, por que não? pergunta a impertinente sobrinha que está lá "em casa"(2) de visita. Por que a Hungria foi diferente dos outros?

Tio Paulo e sua mulher (também médica) se entreolham, fazendo no ar um ponto de interrogação. E, ele, segundos depois, arrisca:

- Acho que foi lobby $y^{(3)}$.

- Que lobby? Pergunto eu.

Rindo muito, o velho dr. Paulo, nascido no raiar do século, exercendo a medicina até hoje (umas horas por dia), diz:

- Acho que tinha muito judeu no primeiro ministério comunista em 1948 e, vai ver, todos tinham parentes médicos. Se algum falasse para proibir, todos concordariam. Mas ninguém falou e ninguém quis lembrar. Quem sabe aconteceu assim!

Já, mais séria, a dra começa a contar que sempre se pôde ter consultório depois do emprego, desde que se pagasse imposto de renda também sobre esse rendimento, mas segundo ela, as pessoas tinham medo. Ela faz clínica geral e diz que, assim mesmo, temia não sabe o quê.

Ele conta que os psicanalistas que quiseram, continuaram a trabalhar, pois ninguém entrou no consultório de alguém para saber o que fazia. Não se fazia psicanálise em hospitais, nem se publicava livros.

A Sociedade de Psicanálise foi fechada (1948) e este foi o segundo êxodo de psicanalistas húngaros. $O$ primeiro foi antes da guerra, fugindo dos nazistas.

Esta foi uma conversa familiar de um casal de médicos aposentados, que conviveram com todos os psicanalistas da pequena cidade de Budapeste. Quando nasceram os primeiros psicanalistas, a cidade apenas nascia da união de Buda, Pest e Ô Buda, três pequenas cidades que se uniram em 1873, justamente no ano que nasceu Sandor Ferenczi.

$\mathrm{O}$ dr. Paulo, confundindo já versōes com histórias, nos conta, ainda, como se tivesse assistido, como foi a primeira aula de Ferenczi na Universidade em $1919^{(4)}$.

- O Ferenczi era um extraordinário conferencista. Quando falava, todos se calavam. As aulas ficavam repletas. A primeira aula ele começou assim:

"Estava muito ansioso em dar esta aula. Afinal, é a primeira vez que dou aula de Psicanálise em Universidade. Aliás, acho que é a primeira vez que isto ocorre no mundo. E assim, preocupado e ansioso sar de casa e vim caminhando. Antes de sair de casa, peguei uma carta que deveria ser posta numa caixa de correio no caminho. Vim pensan-

ANNA VERONICA MAUTNER É socióloga e psicanalista.

1 Esta mesma explicaçăo está na Histoire de la Psycanalise de Roland Jacquard no texto de Jean Palmier e foi também citada por Georges Hidas, psicanalista húngaro, durante uma entrevista em 1989, em Budapeste.

2 Mantive a traduçăo literal do húngaro, pois pareceu fazer sentido. Quando, na diáspora, se fala de Hungria, se diz "em casa".

3 Usa expressăo inglesa.

$4 \mathrm{Na}$ melhor das hipoteses, Paulo Braun teria 15 anos em 1919. Nåo poderia ter assistido a aula de Ferenczi na Universidade. Mas conta com muito realismo à sua parente visitante.

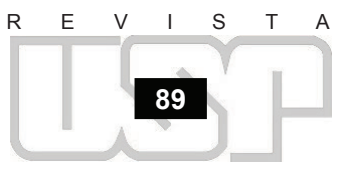


do na aula, mas quando passei pela caixa de correio, imediatamente lembrei da carta, mudei de pensamento, pus a carta e voltei a pensar na aula. Onde ficou o pensamento sobre a carta enquanto não pensava nela?"

E assim teria Ferenczi, segundo meu tio, começado seu curso de Psicanálise na Faculdade de Medicina da Universidade de Budapeste. Seu curso durou só seis meses. Logo, a República dos Conselhos caiu e todas as matérias novas introduzidas no currículo desapareceram junto com seus professores. Os professores e políticos da curta República Marxista foram para as sombras, retornando só lentamente.

O que vou relatar é uma leitura, mais uma escuta e um longo viver de húngara na diáspora. Vou procurar transmitir o que é ser húngaro, sem o que, a psicanálise na Hungria é apenas mais um grupo de psicanálise. A mim pareceu muito mais que isto. É uma história especial que gerou pensamentos originais. Psicanálise na Hungria é húngara. Não importa que todos os psicanalistas falassem alemão com perfeição. Não importa que boa parte deles tivesse parte de sua obra escrita em alemão. "Em casa" (lá na Hungria) ou lá em casa (no recesso do lar) falava-se húngaro. Nosso folclore, nossas raízes, nosso acalanto, nossos nomes, nossa língua, nossa identidade. E esta nos leva à procura da criatividade, independência, autonomia, e fugir por qualquer beco de qualquer ameaça de nos apagar a diferença.

A Hungria é uma nação fóssil. Os magiares vieram para a bacia do Danúbio em torno de 890 d.C. a chamado do imperador carolíngeo, Arnulf. Os magiares viviam, antes, perto das nascentes do Volga, onde hoje é a União Soviética. Pouco antes de atenderem ao apelo de Arnulf, foram viver nas estepes do Don. Viviam em hordas, formadas por tribos, sob a chefia hereditária e tinham uma fraternidade de sangue, real ou imaginária. Esta federação era chamada de On Ogur (dez flechas) $)^{(5)}$.

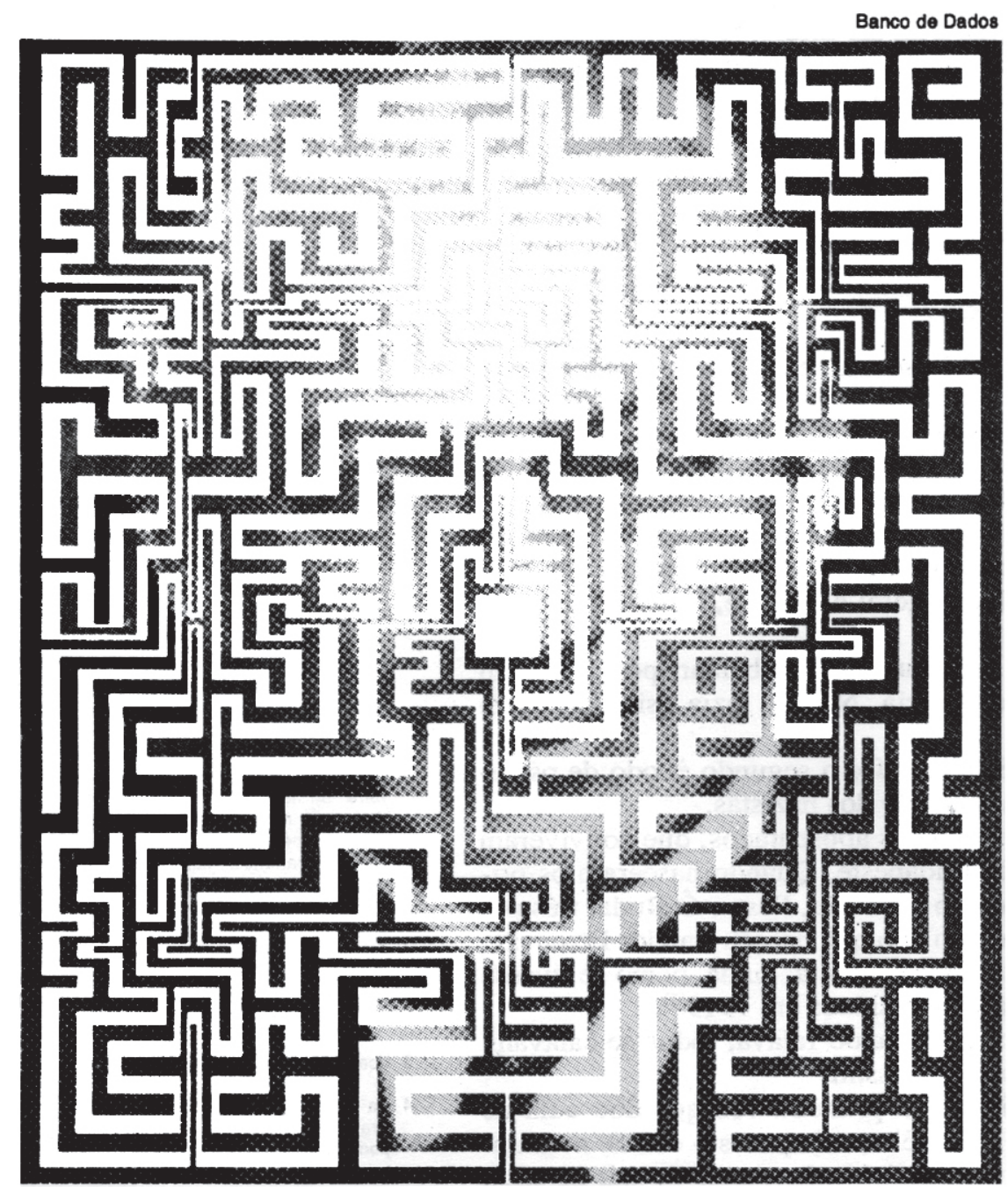

Sándor Ferenczl (1873-1933)

\section{VIENA E BUDAPESTE: UMA HISTÓRIA}

Viena é logo ali. Lá está, com sua coroa e seu brasão de Habsburgo, com suas águias indicando a igualdade das duas nações. Esta pseudo-igualdade foi duramente conquistada. Desde os meados do século XV, quando o imperador da Áustria expulsou os turcos, até 1867, a Hungria foi reconquistando o seu espaço nacional, passo a passo. No dia 29 de maio de 1867 foi estabelecida a monarquia dupla austro-húngara, que durou até 1918.

Em 1868 foi promulgada a "Lei das Nacionalidades", que estabelecia que a Hungria era uma nação indivisível e que a única diferença era o uso da língua própria a qualquer minoria. A língua usada na administração central e na universidade era o magiar. Nos níveis inferiores de comunicação social, podia-se usar a língua das minorias e na vida privada, isto é, no recesso dos lares, também era livre.

Em 1908, quando ocorria a $1^{\text {a }}$ Reunião de Psicanálise, em Salzburg, os húngaros continuavam ainda batalhando pela sua identidade, e é muito diff́cil imaginar que florescesse em Budapeste uma concepção de vida que tivesse origem na capital do imperio, da qual todos queriam se libertar. Na Hungria, em torno dessa luta surda pela libertação, grupos de intelectuais se formavam quase todos os dias, num esforço de completar a frágil identidade nacional atual que, contu-

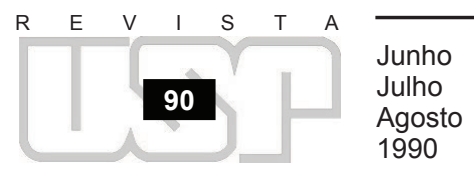


do, como vimos, tinha raízes profundas e arcaicas. Neste momento, autonomia era sinônimo de modernidade, ligação com o ocidente. Mas, esta modernidade, por razões e ressentimentos políticos, não podia vir de Viena, que era tão perto.

Quando, em 1905, teve lugar em Budapeste um congresso antialcoolismo, Fülöp Stein apresenta um trabalho com uma visão psicanalítica, com a qual ele tinha entrado em contato em Zurich, no sanatório de Bleuler.

Em 1907, Jung conhece Ferenczi através de Stein. E Jung acha interessante que Ferenczi conheça Freud. Jung escreve a Freud pedindo que receba Ferenczi e Stein e a entrevista é marcada para 2 de fevereiro de 1908, quando ocorre o histórico encontro a três, Stein , Ferenczi e Freud, em sua casa de campo. (F. Stein, pouco depois, se afasta da psicanálise). Ferenczi já havia lido Freud em 1893 mas não tinha entrado em sintonia.

E assim, vinda da Suíça, a psicanálise pôde ser incorporada ao movimento de modernidade de Budapeste e a aceitação foi galopante. Poetas e prosadores incorporam o pensamento psicanalítico da mesma maneira e ao mesmo tempo que pesquisam as raízes magiares.

Os movimentos, aparentemente de submissão, que encontramos na história da nação húngara, são, na realidade, a procura de apoios para a defesa de sua identidade. Já no século IX, quando Estevão I submete a Hungria à Santa Sé, pela integração ao Sacro Imperio, sob o papa Silvestre I. Parecia que esta cristianização era sujeição, quando, na verdade, era apoio na luta contra outras nações ou tribos que atravessavam a bacia do Danúbio, ameaçando a integridade do povo. E, em 1918, também, a procura do ocidente e de sua modernidade não foi de forma alguma submissão e, sim, um gesto desesperado da burguesia nascente procurando manter a identidade nacional, que, no momento, tinha como ameaça o brasão das duas águias dos Habsburgos e seu afã germanizador. Assim, a psicanálise que vinha da Suíça podia ser aceita, a de Viena, com mais dificuldade. O marxismo, a psicanálise e o simbolismo eram a modernidade libertadora. Mas, a partir de 1909, cinco anos antes da Primeira Guerra Mundial, Ferenczi já tinha se tornado um ardoroso defensor da psicanálise.

Em 1913, nasce o primeiro grupo psicanalítico oficial na Hungria. A grande guerra vai romper as alianças tradicionais e as competições, mas os psicanalistas mantiveram sua união apesar da guerra entre os seus países. E continuavam trabalhando em seus gabinetes, os que não estavam no front. Durante a guerra, Ferenczi escreveu Thalassa, nas horas vagas e entre as batalhas. Como diz ele, na introdução de Thalassa, considerada sua obra-prima teórica, ele tinha dificuldade em viver a tranqüilidade do front; acostumado que era ao intenso trabalho de sua clínica particular em Budapeste. Ferenczi fez durante a guerra uma só análise, a de seu comandante, com o qual cavalgava diariamente, conversando. É conhecida como a primeira psicanálise hípica.

A guerra trouxe à tona um sem-número de neuroses e foi em Budapeste que se abriu a primeira clínica para tratar neuróticos de guerra, em 1918. Foi ainda um outro húngaro, encantado com a psicanálise, que doou dinheiro para a primeira editora de psicanáli$\mathrm{se}^{(6)}$. E o congresso de 1918, apesar de em cima da guerra, foi em Budapeste. Como vemos, foi galopante o contágio da psicanálise na Hungria.

Em menos de seis meses, instala-se a República dos Conselhos de Bela Khun em março de 1919. É o moderno vencendo. E o papel da psicanálise foi extraordinário. Foi reconhecida a importância política da dimensão sexual. Para tanto, basta verificar as leis e decretos baixados pelo novo regime a respeito do papel da mulher, do sexo, do casamento, da religião. A psicanálise ainda foi importante neste momento para explicar a moral rigorosa da aristocracia da terra que tinha que ser substituída por concepçōes de vida mais modernas. Assim vemos como a psicanálise e a política sócio-econômica estavam no mesmo trilho na Hungria, posição completamente diferente da de Viena ou Zurich. Será parecida com a de Berlim uma década depois (Rosa de Luxemburgo).

Esse nascedouro fez a psicanálise participante de toda essa convulsão provocada pelo vôo vazante de uma das águias do brasão. Quando a República dos Conselhos cai, acontece o que Freud mais temia desta mistura: o novo governo do almirante Horthy, naturalmente, via na organização psicanalítica uma ameaça. Roheim é demitido do $\mathrm{Mu}$ seu Nacional, Ferenczi se esconde e a psicanálise continua mas sem contato com o exterior, como já vinha acontecendo desde 1914. O lema do novo regime ficou sendo: "psicanálise de gabinete sim, de massa não", igual ao que aconteceria durante o regime stalinista futuramente.

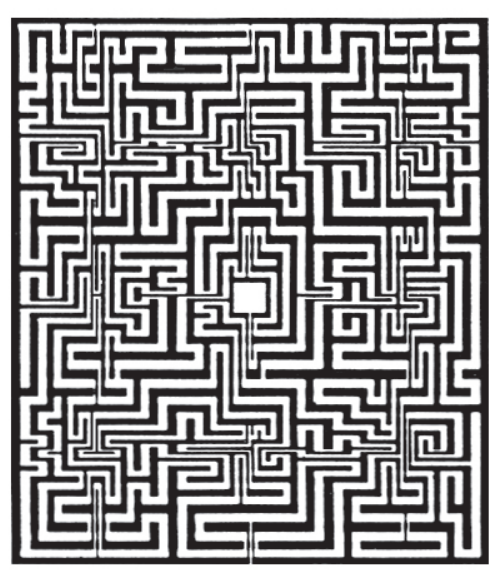

5 Enciclopédia Britânica.

6 Anton von Freund.

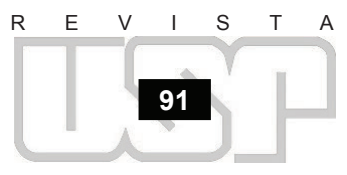




\section{Viena ERa logo ali no espaço e na Polftica.}

\section{(Império Austro-Húngaro, duas águias em um só brasão)}

Entre 1917 e 1919, Londres era mais acessível aos vienenses que Budapeste, por causa da guerra.

Apesar dos insistentes apelos de Freud para que os psicanalistas da Hungria se mantivessem reservados quanto à política, isto foi impossível. Cada psicanalista era um batalhador, da batalha maior, a da libertação da nação e sua futura inserção no ocidente moderno. O nascedouro da psicanálise húngara foi neste cadinho comum. Foi inevitável a psicanálise estar presente aos movimentos intelectuais e revolucionários com vistas à sua separação do conjunto do Império. Também foi impossível em 1919 não participar da República dos Conselhos de Bela Khun. Era um só movimento, mobilizando todos os setores impregnados de modernidade.

A psicanálise, que depois da Primeira Guerra Mundial já começava a conquistar espaço nos hospitais e ćŕrculos científicos oficiais, vai perder o espaço conquistado e entrar em semi-clandestinidade, quando da derrocada de Bela Khun.

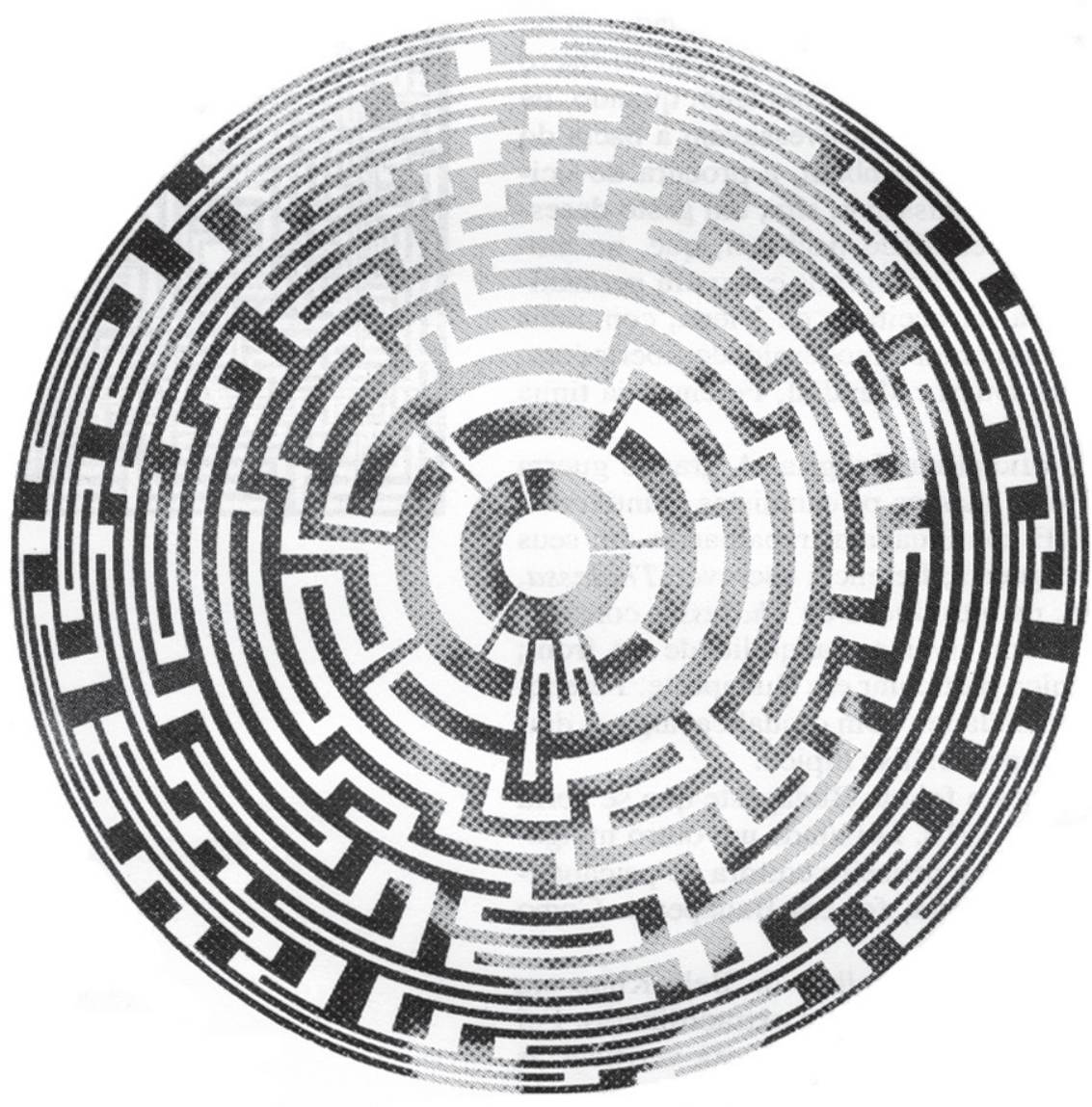

Findo o Império, a nação húngara torna-se um estado totalitário, anti-semita, que só muito lentamente se liberaliza; e os psicanalistas, arantos da modernidade, formados quase que totalmente de judeus, vão sair das sombras, para uma liberdade tolerada, mas nunca mais garantida ${ }^{(7)}$.

Nesta época pós-guerra, Ferenczi é o todo protetor em torno do qual gira a psicanálise na Hungria. O Dispensário Psicanalítico, inaugurado em 1917, volta a funcionar timidamente e a Sociedade também volta ao normal sob este mestre protetor, porém não subjugador, que nem faz questão de exercer dominação intelectual. Se por um lado ele mantém uma relação íntima com Freud e até de obediência ${ }^{(8)}$, por outro lado é intelectualmente livre, como seus discípulos o são. Seus temas, suas contribuições técnicas ${ }^{(9)}$ mereceram ora o respeito, ora a desaprovação de Freud, mas Ferenczi continuou seu caminho, que tinha a ver com sua profunda dedicação à clínica. Para ele não era a técnica, o limite. $\mathrm{O}$ paciente merecia a expansão da técnica, novas experiências, criatividade, ousadia, para "tudo tentar" na direção da cura.

Ferenczi manteve este grupo inovador, criativo, ligado, não a um mestre, mas a uma idéia. Os húngaros não puderam ser filhos de Freud, mas foram filhos diletos da psicanálise, que, aliás, espalharam pelos quatro cantos da Terra em seus sucessivos êxodos.

Vista de fora, a psicanálise húngara e o nome de Ferenczi se misturam, pelo menos num primeiro momento. Analisando, porém, com mais cuidado, percebemos que esta visão é preconcebida. Como chamar de escola um grupo com interesses tão heterogêneos? Dr'- Livia Nemes, discípula dileta de Herman, diz que a psicanálise húngara é uma "otica", não um grupo. É a ótica húngara.

Estão na ótica húngara: Balint, Roheim, Spitz, Zsondi, Melanie Klein, Herman, Sze-

7 Vemos situaçăo semelhante na década de 70, apלs o terror stalinista.

8 Năo se casou com a mulher que amava porque Freud achava a diferença de idade excessiva. Casou-se com a máe da amada, que era mais velha que ele e, por isso, năo teve filhos.

9 Técnica ativa. kács, Rajka, Rad, Lorand, Franz Alexander. Cada um usa esta ótica aplicada ao seu campo de interesse, onde estiver morando.

A origem judaica de quase todos levou-os à dispersão no fim da década de 30 , fugindo do nazismo, e, mais ainda, depois da guerra, fugindo do comunismo. Vejamos alguns exemplos: M. Balint foi analisdo por K. Abraham em Berlim e emigrou mais tarde para Londres; R. Spitz foi discípulo de Anna Freud e emigrou para os Estados Unidos;

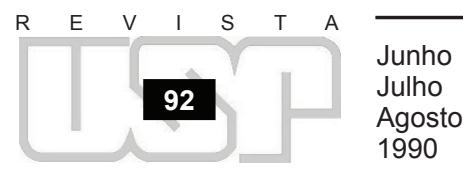


L. Zsondi formou-se em Zurich; G. Roheim foi analisado em Leipzig e Berlim e emigrou para os Estados Unidos; Herman formou-se em Budapeste e nunca emigrou. Publicou livros sobre técnicas, lógica e, ainda, sua teoria sobre "reflexo de agarrar e se desprender"' $(1943)^{(10)}$.

Suas idéias foram usadas não só por psicanalistas, mas, também, por antropólogos. Foi, juntamente com Estevão Szekács, o pai da nova geração de psicanalistas.

Depois da Segunda Guerra Mundial (1945), poucos psicanalistas restaram em Budapeste e, dentre estes poucos, uns 15 mais ou menos, ainda alguns emigraram antes da implantação do stalinismo. O stalinismo encontra uma Sociedade de Psicanálise viva, mas esvaziada. Tinha caciques, mas faltavam índios. Mais uma vez a psicanálise se esconde e aguarda melhores dias. Em 1948 a Sociedade é oficialmente fechada. Razões políticas, suicídios e medo determinaram mais deserções.

Como vimos na introdução, a psicanálise na Hungria não foi totalmente clandestina durante o terror stalinista, pois que a prática particular de medicina nunca foi abolida. Mas, também, não foi nunca ratificada. Os analistas temiam essa frágil liberdade e cada um tomou um emprego público e, eventualmente, atendia um ou dois pacientes por dia.

De imediato, surgiu uma cisão dentro do pequeno grupo que restou, entre Herman e Szekács ${ }^{(11)}$. O contato dos psicanalistas com o exterior foi extinto e seus membros dispersos por vários órgãos estatais e várias funções médicas e paramédicas.

\section{DURANTE QUINZE ANOS FEZ-SE SILÊNCIO (1949-65).}

Em torno de 1965, os psicanalistas começaram a sair da toca. Nesta altura, o rompimento de Herman e Szekács ainda se mantinha, mas os mais jovens médicos e psicologos começam a se reunir, aos domingos, em casa de Herman, para seminários.

Em 1969 se comemorou publicamente, com grandes festividades, o 80 aniversário de Imre Herman e até psicanalistas do exterior vieram. Foi uma primeira importante retomada.

Outro psicanalista nascido na primeira década deste século, Tibor Rajka, procura desde 1965 oficializar o "grupo de estudos" diante da IPA ${ }^{(12)}$. Foi outro grande arquiteto da retomada, junto com Georges Hidas. Em 1968, no Congresso de Psicanálise, Herman e Rajka entram em contato extra-oficial com a IPA, mas Herman, da velha guarda, gato escaldado por tantas repressões, não aceita supervisão da IPA, de medo do governo intervir.

Nesta época, Hidas e outros começam a fazer "grupos de encontro" com médicos e enfermeiros no interior da Hungria.

Este movimento foi um passo de coragem para provar que a instalação de "grupos oficiais de estudo" era possível. Este trabalho durou mais de dez anos ${ }^{(13)}$.

No histórico Congresso de Viena em 1971, Hidas, Rajka e outros criam um comitê de ligação com a IPA. Tudo isso feito à revelia de Imre Herman. Em 1975, no Congresso de Londres, foram legalizados os grupos de estudo pelo éntão presidente da IPA, Lebovici, que até visitou Budapeste oficialmente.

Na década de 70, o grupo húngaro estava com as vistas voltadas para o ocidente, visitando e sendo visitados. O ocidente ia ficando cada vez mais próximo até que, em Roma (1989), a Hungria se integra à IPA.

É uma longa e tenebrosa história de um povo, de uma classe e de um ofício. Como se tudo fosse uma coisa só. Destinos comuns. Se não ficou claro, agora quero reiterar. $\mathrm{O}$ absolutismo e o totalitarismo foram inimigos figadais da criatividade e seu corolárioautonômio social, nacional e pessoal. O caráter inovador permanente da psicanálise a torna inimiga nata de qualquer forma de totalitarismo.

Os regimes totalitários sabem que a psicanálise vive da liberdade e gera liberdade, mesmo que em certos momentos detectemos o contrário (o contrário dura pouco). Não há paradoxo na relação psicanálise/política. Ser psicanalista é estar livre diante do paciente, senão dita-se regras, não se analisa. Por isso, nesta longa história húngara de procura da autonomia e defesa da identidade, a psicanálise cresce e murcha junto com movimentos sociais. A psicanálise na Hungria caminha lado a lado com a história política e social da Hungria neste século.

\section{TEMAS E HERANÇAS}

Os desastres que atingiram a Europa Central e a Hungria por conseguinte foram mo-

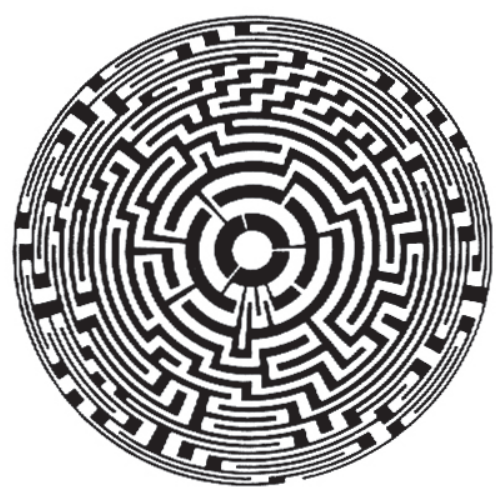

10 Instinto filial.

11 Romperam em 1948 por razoes pessoais e polfticas.

12 International Psychoanalitical Assoclation.

13 Entrevista com Georges Hidas.

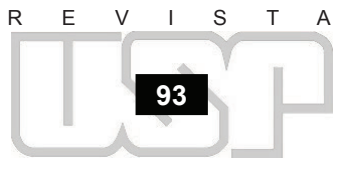




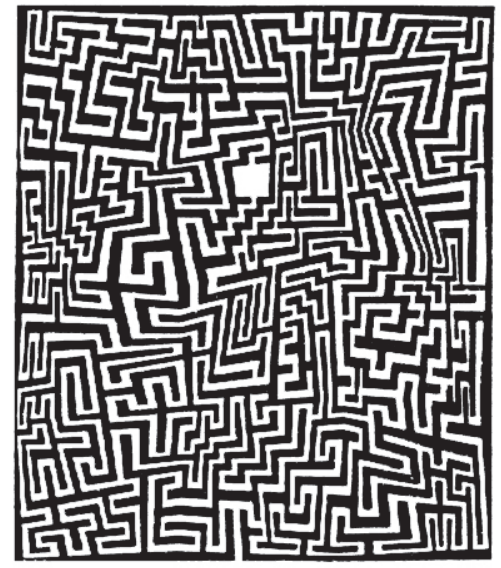

14 Ferenczl leu Freud em 1893, mas năo fez sintonla.

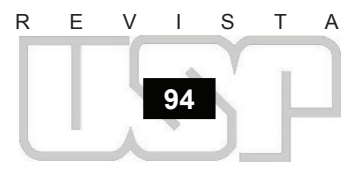

mentos de fluxo e refluxo do movimento psicanalítico que, pois, ora florescia, ora ficava inerte, ora se escondia.

\section{Lutas pela nacionalidade \\ Primeira Guerra Mundial \\ República dos Conselhos \\ Totalitarismo Nazi-Fascista \\ Segunda Guerra Mundial}

Em momentos a Áustria era a odiosa sede do Império, ora era o ocidente, ora moderno era ser marxista, ora Marx era meio de opressão de Moscou. Estes sonhos desconexos e desencontrados atingem as relações dos profissionais e o meio social que os contém. Os reflexos desta íntima relação, naturalmente, influem, também, nos interesses teóricos dos colegas húngaros. A procura da compreensão dos milênios de luta pela identidade social tinha que ser uma interrogação na pesquisa das motivações humanas. Não é à toa que Ferenczi, um ano depois de conhecer Freud (1909), escreve uma pequena obra, teoricamente importante: Introjeção e transferência. O conceito de introjeção primeiramente defendido por Ferenczi ${ }^{(14)}$ cai como uma luva no questionamento de tanto esforço de autopreservação, por tantos séculos, tanto pelos magiares, quanto pelos judeus, que eram a grande maioria dos psicanalistas húngaros.

Como interagir e criar sem se diluir? Qual e onde está o limite?

Outro campo de estudo muito prestigiado foi o da formação dos próprios psicanalistas. Nas condições húngaras deste século, a formação dos analistas passou várias vezes de "o mundo germânico todo ao seu dispor" à quase clandestinidade. Formar psicanalistas na abundância e na carência é uma situação que obriga a pensar, se adaptar e ser flexível.

Assim, o interesse pela relação mãe-filho (em Ferenczi, Balint, Spitz, Herman) também se encaixa em um grupo que não pôde aceitar pai Freud (dominador vienense) e que foi várias vezes privado de alimento (relação com o exterior). Como se desenvolver em condições tão adversas? E, quando isolados, clandestinos por forças externas ou por autodefesa, coube-lhes espaço para misturarem-se com profissionais de outras áreas.

É na escola húngara que se tenta mais freqüentemente confrontações audaciosas com outras ciências: Biologia (Ferenczi, Herman); Antropologia (Roheim); Medicina (Balint); Lógica, Epistemologia e Matemática (Herman).

Minhas explicações nesta parte sobre os temas não só são audaciosas (como boa húngara), mas, também, simplistas. É uma ilustração apenas. As relações podem não ser evidentes. Mas, por que não arriscar no óbvio? Âs vezes a gente pode acertar ou fazer pensar, pelo menos.

Na psicanálise húngara não só predomina a independência entre seus membros, cada um segue seu caminho, como certos sistemas são conservados, como, por exemplo, a supervisão. Os húngaros foram ardorosos defensores da criação da análise de controle e da análise de treinamento: o que é novamente compreensível à luz das aproximaçōes e afastamentos sofridos pelo grupo. É uma das faces da relação mestre/discípulo ou mãe/filho. Em 1933, Wilma Kovács publica seu artigo "Training analysis and control analysis" no Memorial Book de Ferenczi, quando da morte deste.

O sistema de Wilma Kovács ainda é seguido na Hungria e defendido como aprendizagem realizada na experiência analítica, e o deslocamento da associação livre para a associação livre em temas.

É muito difícil definir as diferenças temáticas entre Viena, mundo e Budapeste, sem entrar em intrincadas discussões não apenas técnicas e teóricas, mas também epistemológicas. O que, claro, não farei aqui porque não sei e porque não caberia. Mas eu gostaria, neste subtítulo, de, magiarmente, ousar a apontar na psicanálise húngara um certo viés fenomenológico que a coloca a uma certa distância do positivismo determinista germânico ou pelo menos vienense.

É preciso uma parada aqui para já responder a quem me acuse de magiar demais. A psicanálise húngara tratou em seus escritos muito mais da cura, do desaparecimento dos sintomas, do que Viena. Mas isto não a torna mais determinista. É na ênfase do cuidar, amar, dedicar-se que a "cura" se localiza. São abstrações próprias da técnica magiar. O holismo - integração do sensorial na vida psíquica -, sempre presente de Ferenczi a Rajka, $\varepsilon$ outro aspecto que diŕamos puxar para uma abordagem fenomenológica. A tendência a alargar o campo da psicanálise, com a tentativa de tratar pacientes que a psicanálise clássica considerava fora de seu âmbito, também nos leva a ver na concepção lo- 
cal de Herman uma visão mais abrangente que incluiu tratamento de psicopatas, limítrofes, etc.

São tecnicidades que trago aqui apenas para indicar possíveis temas para futuras abordagens da relação entre o mundo que nos circunda e o pensamento analítico.

\section{Conclusão mais Que Pessoal (BIBLIOGRAFIA COMENTADA)}

Descobrir, ver debaixo do que cobre, é o que ocorreu comigo lendo a história da Hungria na Enciclopédia Britânica.

Descobrir sobre a psicanálise e psicanalistas húngaros - o cotidiano e a obra - foi na leitura da Histoire de la Psychanalise de Jean Jacquard, artigo de Jean Palmier.

Ler o no 82 inteiro do Le Coq Heron, dedicado à psicanálise húngara foi uma informação farta sobre quem anseia por saber mais sobre a profissão na Hungria e na sua diáspora.

E quanta informação e emoção em um artigo apenas mimeografado sobre Tibor Raj$\mathrm{ka}$, escrito por quatro de seus ex-clientes.

Os livros de Imre Herman que encontramos foram três fontes copiosas de informação. Ferenczi é um caso à parte. Suas obras completas são traduzidas (as de Herman também) e acessíveis há muitos anos. Só sua correspondência com Freud é que permaneceu sob censura dos herdeiros de Freud. Algumas cartas são citadas por Ernest Jones e outros, mas a vasta correspondência trocada de 1908 até 1933 constituiu o grande segredo e desperta, pois, a maior curiosidade.

A supervisão na Hungria foi objeto de importantes escritos de Wilma Kovács (1933), de Ernest Loch e muitas referências. As entrevistas que fiz no início deste ano com Georges Hidas, Ildiko Erdely e Judith Szekács lá em Budapeste na semana da queda do muro de Berlim teve este sabor de mudança e esperança ao vivo.

Foi um mergulho na minha própria alma rebelde. Quanto mais ouvia ou lia, mais me encontrava e podia sentir o que de específico tem a psicanálise húngara. Esta profundidade na flexibilidade é a estreita ligação com tudo que rodeia e acontece. Falta-lhe o "ar de seita" que encontramos às vezes por aqui. É uma psicanálise do mundo, nada convencional. Arremedando Nelson Rodrigues: ser psicanalista húngaro é um "estado de espírito".

Relendo, percebi que falta referência a um tema que intur durante este mergulho. Pela

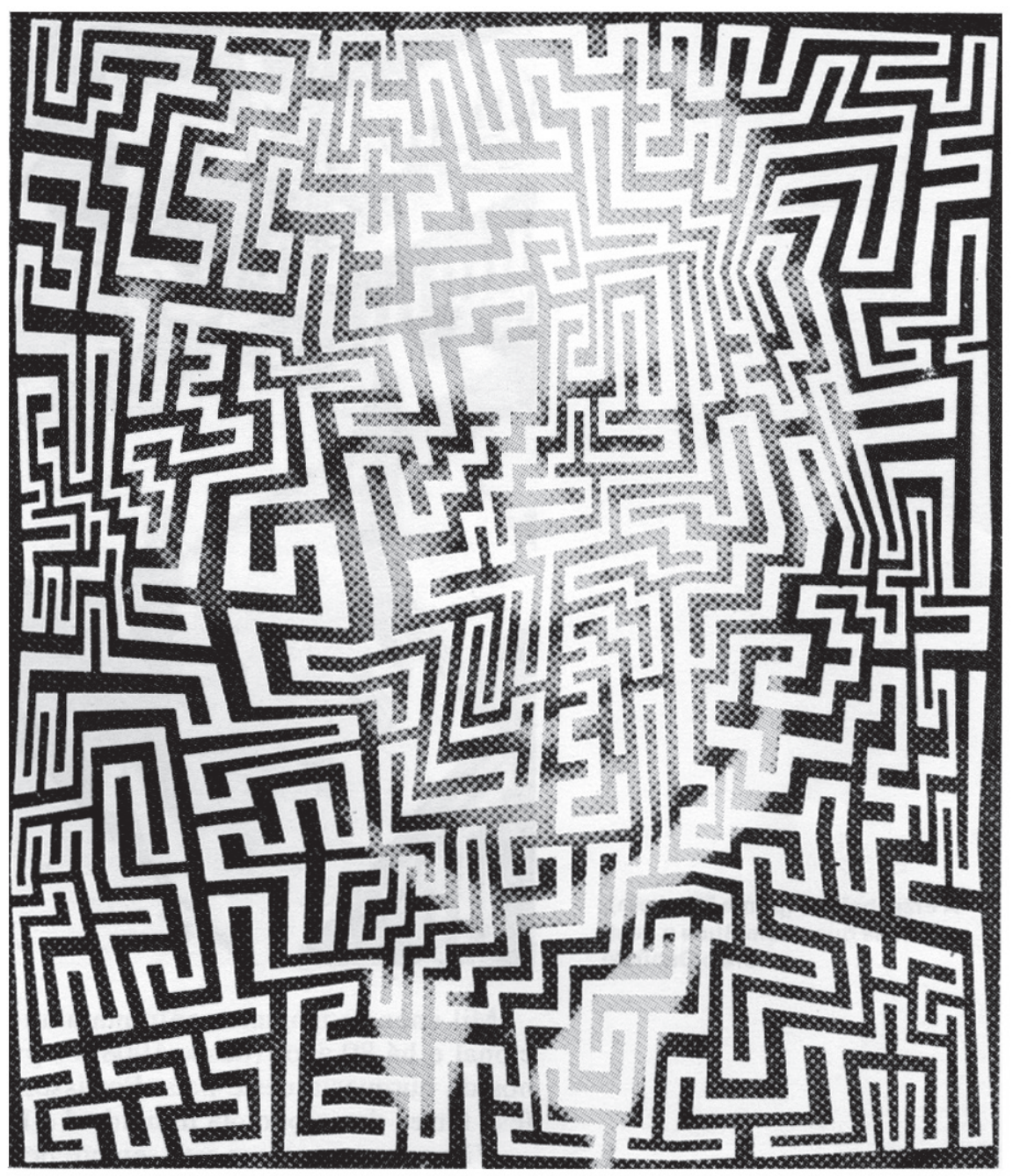
língua "que mamãe falava comigo" foram todas as lutas do ano 800 até hoje. Neste século a luta foi renhida, e a psicanálise atrelou-se à briga pela sobrevivência da herança magiar e sofreu todos os percalços desta trajetória. Nestes dois séculos esta luta foi encabeçada pela burguesia nascente donde vieram todos os psicanalistas e - $\mathrm{a}$ isto some-se serem quase todos judeus -, cujo destino foi ainda mais crítico neste século nas malhas do nazi-facismo.

Viajando pela Hungria e Tchecoslováquia em janeiro de 1990, durante a queda de Ceaucescu, derrubada do muro de Berlim, etc., senti o quanto a racionalidade e lógica marxista-leninista deixou intocada a questão de língua e nacionalidade. Continua-se a morrer para manter a língua materna. 


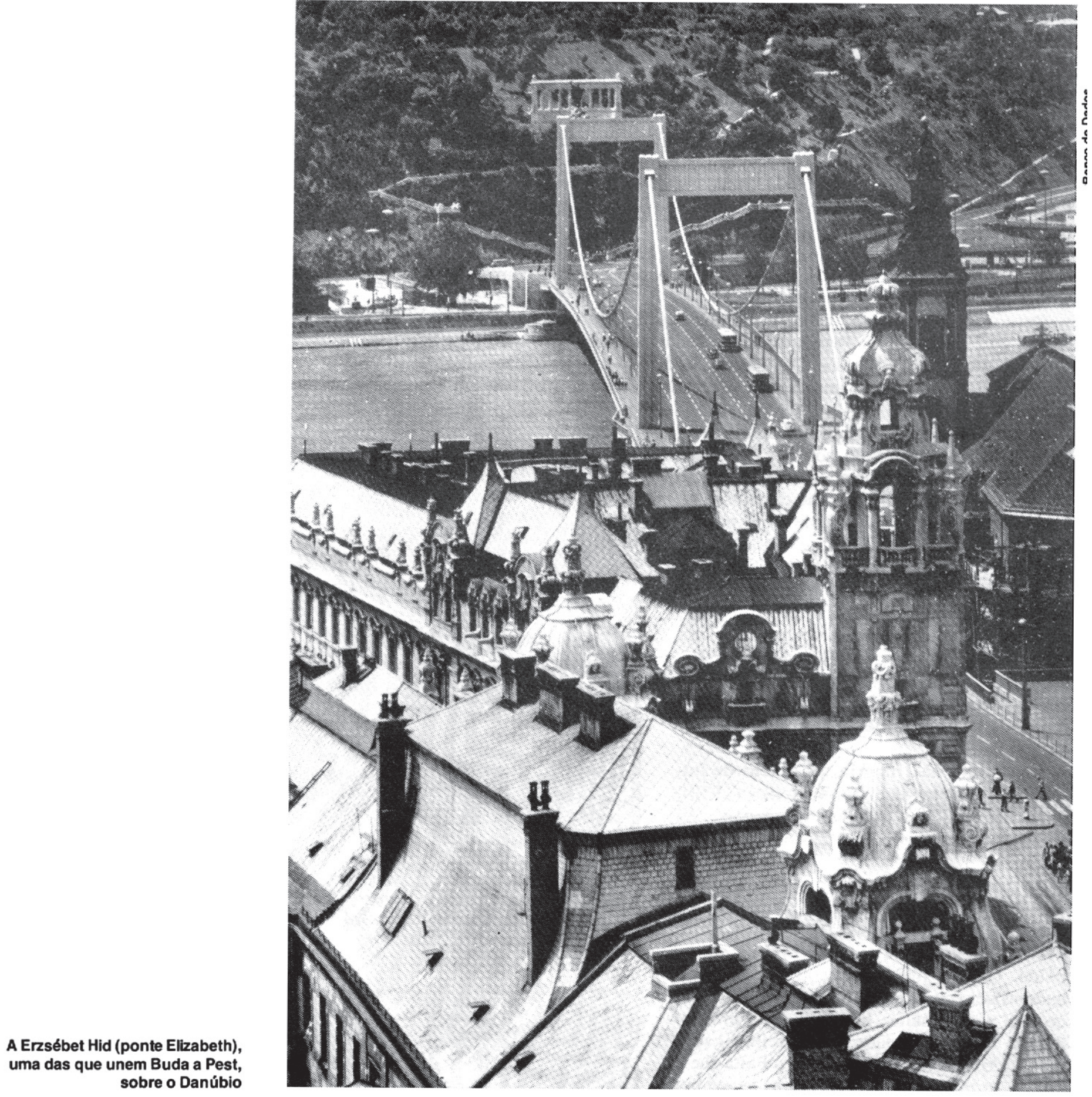

Mil anos os magiares enfrentaram todos em sua volta para manter-se como grupo nacional e há 80 anos (desde 1908) os psicanalistas húngaros seguem acoplados aos destinos da burguesia neste país. Por isso, ousados e flexíveis na mesma medida de sua defesa férrea da autonomia individual e liberdade.

Viena ou o opressor está sempre perto demais.

A Fundação Fullbright concedeu, no fim do ano passado, uma bolsa de dois anos para uma psicanalista americana de ascendência húngara pesquisar o que aqui ouso esboçar. Vamos esperar o trabalho dela. Não me disseram o nome da pesquisadora. (Informação de Georges Hidas.)

Ser psicanalista judeu húngaro da diáspora é ter nostalgia pelo paraíso idílico nunca vivido. Ser psicanalista judeu na Hungria é sonhar sem parar em sentir a nostalgia dos que estão na diáspora.

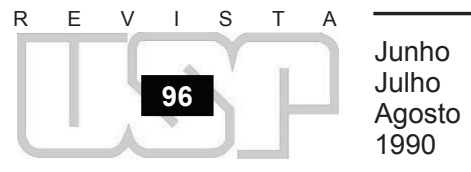

